\title{
Simulation of power lines with longitudinal compensation device
}

\author{
Vitaly Novokreshchenov ${ }^{1}$ \\ ${ }^{1}$ Kazan State Power Engineering University, 51, Krasnoselskaya street, Kazan, 420066, Russia
}

\begin{abstract}
With series compensation of the line reactance, the problem of its protection against overcurrents arises regarding relay protection. The greater the degree of compensation, the greater the problem. When compensating for more than $50 \%$ of the reactance of the line, the protection of power transmission lines becomes practically impossible due to the failure or false operation of all existing kinds and types of protection [1,2]. Therefore, as for now, the compensation of the line reactance usually is no more than $50 \%[3,4]$, which does not allow to reveal the full potential of the line in terms of its transmission capacity. The goal of this research was to study the processes occurring in emergency modes on power lines equipped with a series capacitor bank, the understanding of which would help to produce algorithms that can protect power lines with SCB with a degree of the longitudinal resistance compensation of the line of more than $50 \%$.
\end{abstract}

\section{Introduction}

There are several ways to increase the transmission capacity of power lines in the power industry. One of the ways is to install a line of capacitor banks in series to compensate for the reactive resistance of power lines [5, 6]. This technical solution, apart from advantages, also has some disadvantages. With a compensation coefficient of more than $50 \%$ of the line reactance, the following phenomena are observed: current inversion during a short circuit, voltage inversion during a short circuit, low-frequency oscillations after a short circuit is disconnected, etc. [7, 8]. These (and other) phenomena lead to the impossibility of protecting the power transmission line since they lead to the false operation or malfunction of relay protection in case of damage on the protected line $[9,10]$. In particular, the inversion of the current with a short circuit on the line leads to the fact that the currents are not directed to the place of the short circuit (see Fig. 1), but, as it were, in transit past it (see Fig. 2), as a result, the differential and phase comparison protection perceives this damage as external and does not work [11, 12]. For this reason, the reactance compensation of the power transmission line does not exceed $50 \%$ right now [13].

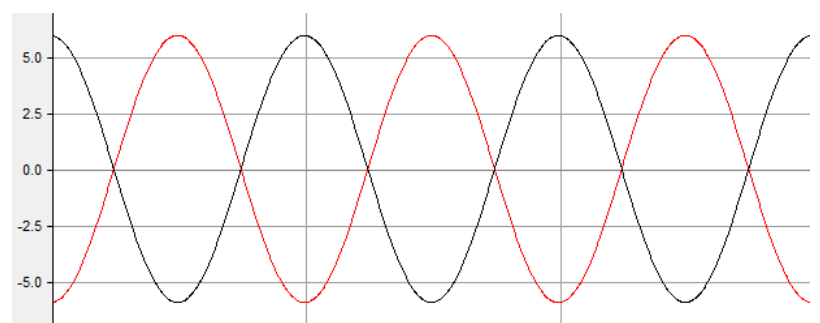

Fig. 1. Oscillogram of currents at a three-phase short circuit in the middle of a line with two-way power supply without longitudinal compensation (currents from different ends of the line are shown in different colors).

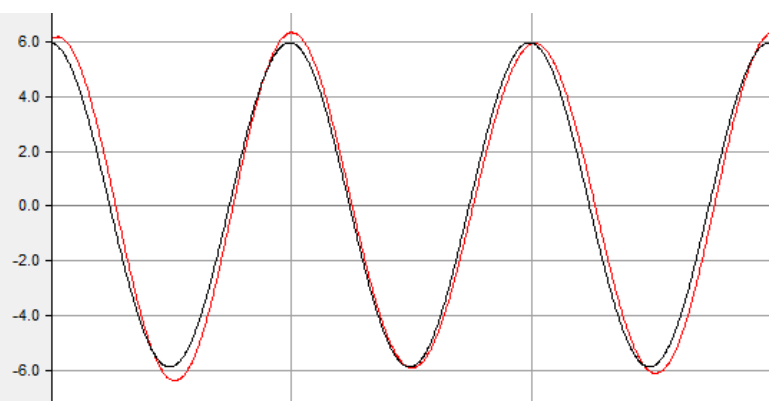

Fig. 2. Oscillogram of currents at a three-phase short circuit in the middle of a line with two-way power supply with longitudinal compensation (currents from different ends of the line are shown in different colors).

The goal of this research is to analyze the influence of series capacitor banks on the emergency mode parameters of the power transmission line.

\section{Materials and methods}

One circuit of the Bratsk-Irkutsk $500 \mathrm{kV}$ power transmission line was assembled in the PSCAD software environment, the equivalent circuit of which is shown in Fig. 3. The model includes two ideal three-phase voltage sources interconnected by means of 20 U-shaped sections of the line equivalent circuit (see Fig. 4 and Table 1). In the middle of the power transmission line (between the 10th and 11th segment), an ideal capacitor is connected to each open fault. At the junction of each of the sections of the power transmission line, symmetrical short circuits with a transition resistance of $0.01 \mathrm{Ohm}$ were simulated. 


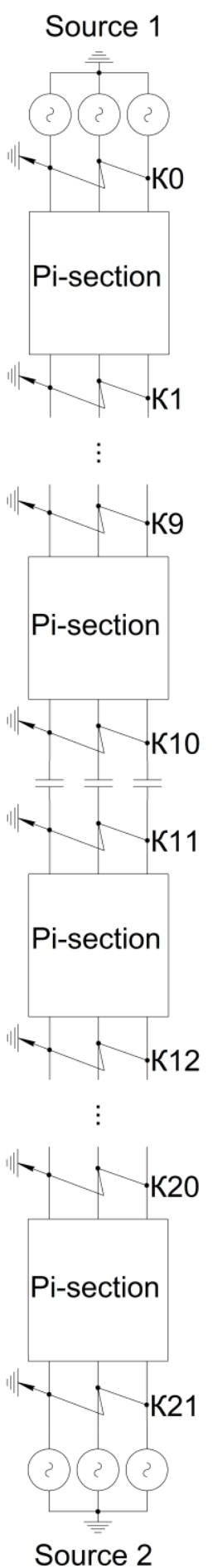

Fig. 3. Equivalent circuit for a longitudinal compensation line connecting two power systems.

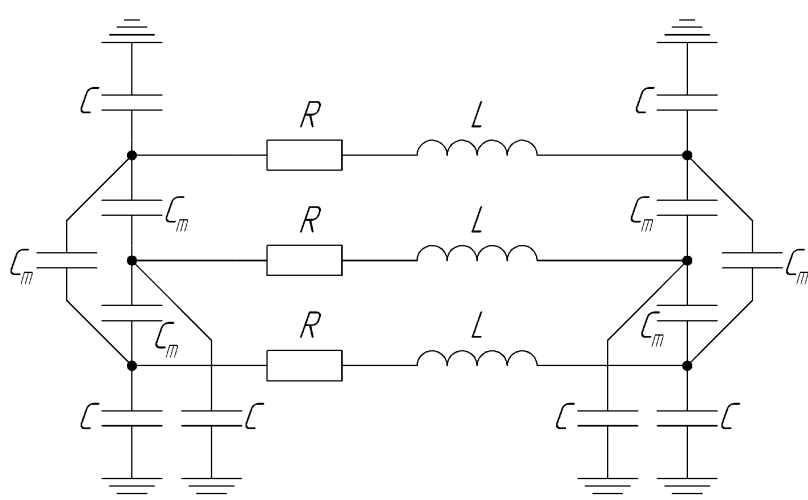

Fig. 4. The equivalent circuit of the power transmission line.

Table 1. List of elements used in the equivalent circuit and their technical characteristics.

\begin{tabular}{|c|l|l|}
\hline $\begin{array}{c}\text { Designation } \\
\text { in circuit }\end{array}$ & \multicolumn{1}{|c|}{ Name } & \multicolumn{1}{|c|}{ Technical data } \\
\hline$R$ & $\begin{array}{l}\text { Active resistance } \\
\text { of the wire }\end{array}$ & $\begin{array}{l}\text { Direct sequence: } \\
0,1781598 \times 10^{-4} \\
\text { Ohm } / \mathrm{m} . \\
\text { Zero sequence: } \\
0,2952201 \times 10^{-3}\end{array}$ \\
& & Ohm $/ \mathrm{m}$. \\
\hline$L$ & Inductive & $\begin{array}{l}\text { Direct sequence: } \\
0,31388 \times 10^{-3} \\
\text { Ohm } / \mathrm{m} .\end{array}$ \\
& resistance of the & Zero sequence: \\
& wire & $0,1039898 \times 10^{-2}$ \\
& & Ohm $/ \mathrm{m}$. \\
\hline$C$ & Capacity & $414,1642 \mathrm{MOhm} / \mathrm{m}$ \\
& reactance between & \\
\hline$C_{m}$ & Wire and ground & \\
\hline & Capacity & $273,5448 \mathrm{MOhm} / \mathrm{m}$ \\
& reactance between & \\
\hline & wires & \\
\hline
\end{tabular}

\section{Results}

To analyze the influence of the SCB compensation on the parameters of the power transmission line modes, short circuits were simulated at the junction of each of the segments. The research was carried out in several stages. At the first stage, emergency modes (SC) were simulated with different degrees of SCB compensation. At the second and subsequent stages, emergency modes were simulated with different initial parameters of the model (time of a short circuit occurrence, voltage difference at the ends of the line, etc.) with a fixed value $(100 \%)$ of the degree of series compensation.

\subsection{Research of the influence of compensation of series capacitor banks on the parameters of emergency modes of the power transmission line}

To research the influence of the series capacitor banks compensation on the parameters of emergency modes of the power transmission line, short circuits were alternately simulated at each point of the short circuit 
with a fixed transfer resistance $(0.01 \mathrm{Ohm})$ and various degrees of series compensation - from 0 to $100 \%$. Since the power line model was initially divided into 20 sections, the step between the short circuit points was $5 \%$ of the line length. Based on the data obtained, a graphical dependence of the shear angle between currents from different ends of the line on the distribution of the SC point and the degree of series compensation was plotted (see Fig. 5). The direction from the busbars to the line is chosen as the positive direction of the currents. Since the dependence of the phase shift on the location of the short-circuit point is symmetrical with respect to the SCB (relative to the middle of the line), only the left half of the graph is shown in the figure (from the 1st to the 10th point). Point 0 on the graph is not given due to the fact that the angle between the vectors with a short circuit at this point greatly depends on the internal resistance of the power source and/or the resistance between the source and the power line.

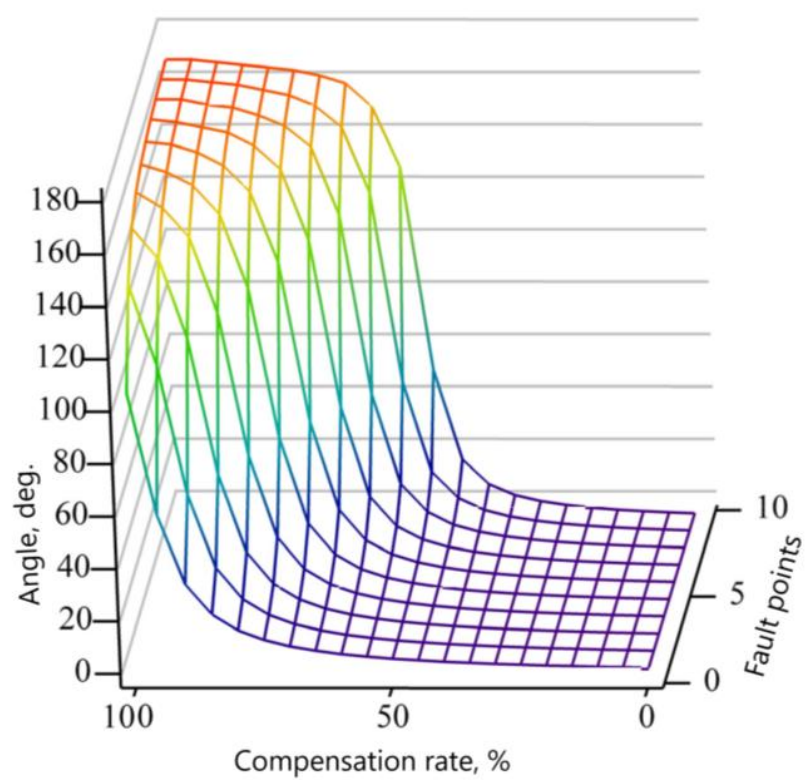

Fig. 5. Dependence graph of the shear angle between the vectors of currents of the same phases at different ends of the line from the location of the short circuit point and the degree of series compensation.

As research has shown, and as the graph shows, the closer the SC point is to the SCB, which is located in the middle of the line, and the greater the degree of series compensation, the greater the angle between the vectors of currents of the same phases, and the dependence is nonlinear.

Also, during the research, it was noticed that when at least some small degree of series compensation appears, a subsynchronous damped sinusoid appears in currents flowing from the capacitor side (see Fig. 6). The frequency of the subsynchronous sinusoid increases with an increase in the degree of series compensation. Moreover, with a compensation degree of $20 \%$ or more, the frequency of the subsynchronous sinusoid becomes more than half of the power frequency, which is why the phenomenon of amplitude modulation begins to be observed (see Fig. 7).

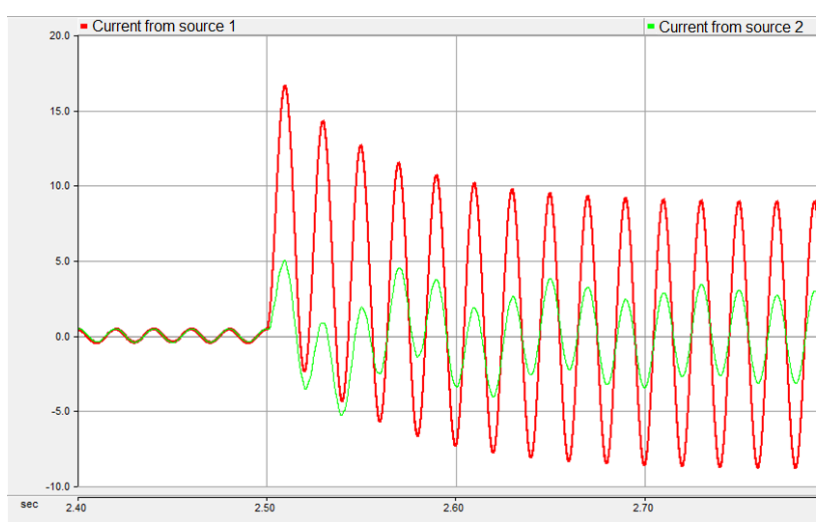

Fig. 6. Short-circuit currents at K5 point (compensation degree $5 \%$ ).

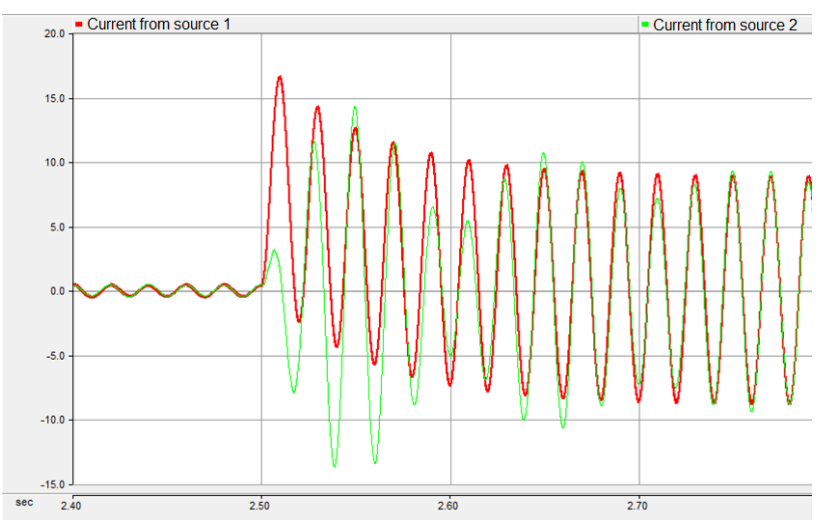

Fig. 7. Short-circuit currents at K5 point (compensation degree $50 \%$ ).

When the capacitance of the SCB is such that during a short circuit, the degree of compensation of the inductive resistance of the line section, located on the capacitor side relative to the short circuit is close to $100 \%$, the currents are at an angle of $90^{\circ}$, and the transient process on the capacitor side is accompanied by a symmetric exponential increase in amplitude (see Fig. 8).

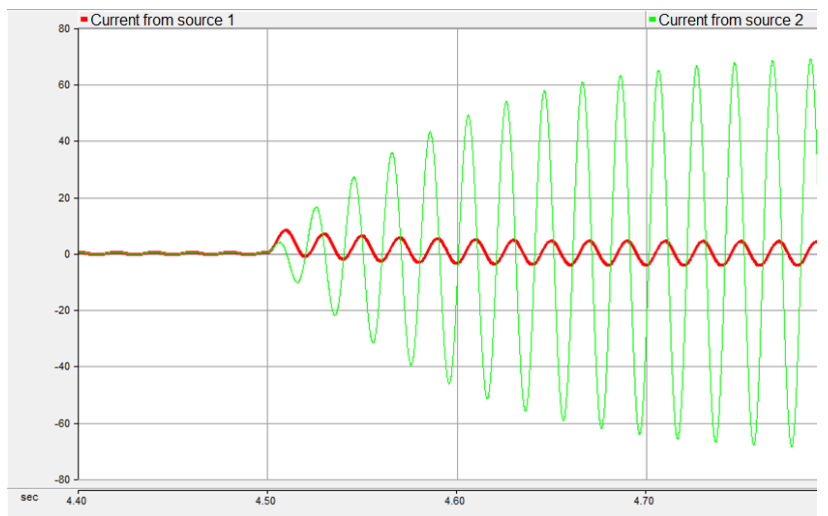

Fig. 8. Short-circuit currents at K10 point (compensation degree $50 \%$ ).

In the case of overcompensation of the inductive resistance of the damaged section of the power transmission line (i.e., with a compensation degree of 
more than $100 \%$ ), the behavior of the transient process is mirrored with respect to one hundred percent compensation of the damaged section: as overcompensation, the subsynchronous frequency begins to decrease.

\subsection{Research on the influence of the time of a short circuit occurrence on the emergency modes parameters of a power transmission line equipped with a series compensation device}

To study the influence of the time of a short circuit occurrence, symmetrical three-phase short circuits were alternately simulated at points K0 - K21 with the following parameters: voltage of three-phase sinusoidal voltage sources: $500 \mathrm{kV}$; series compensation of inductive resistance: $100 \%$; the difference in voltage of the same phases angles: $0^{\circ}$; the transition resistance at the short-circuit point is $0.01 \mathrm{Ohm}$ (purely active resistance). During the research, it was found that despite the almost complete inversion of currents in the steadystate short circuit mode, at the very initial moment of the short circuit, the currents are directed to the point of the short circuit (see Fig. 9). The direction from the busbars to the line is taken as the positive direction of the currents.

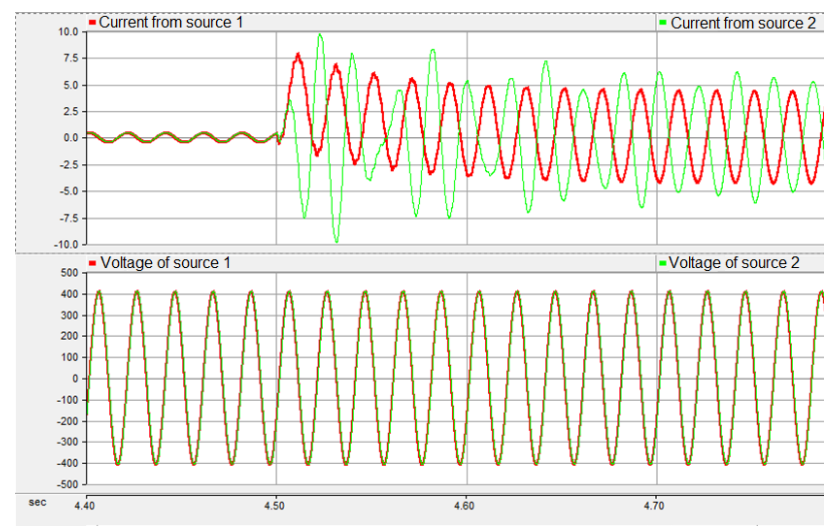

Fig. 9. Short-circuit currents at the K10 point (beginning of short-circuit at $330^{\circ}$ voltage angles).

It has also been found that when a short circuit occurs in the immediate vicinity of the SCB at the time when the phase voltage is "on the wave crest" $\left(90^{\circ}\right.$ and $270^{\circ}$ ), small harmonic distortions of currents are observed, both from the side of the uncompensated section and from the side of the series compensation device. While at angles other than the above-mentioned ones, this phenomenon is not observed.

\subsection{Study of the active power flows influence caused by the voltage difference at the ends of the power transmission line on the emergency mode parameters of the power transmission line equipped with a series compensation device}

To study the influence of active power flows, symmetrical three-phase short circuits were alternately simulated at points $\mathrm{K} 0-\mathrm{K} 21$ with the following parameters: voltage of the three-phase sinusoidal voltage sources was taken $515 \mathrm{kV}$ and $460 \mathrm{kV}$ alternately to load the line with its rated current; the series compensation of inductive resistance: $100 \%$; the difference in angles of the same phases in voltage: $0^{\circ}$; the transition resistance at the short-circuit point is $0.01 \mathrm{Ohm}$ (purely active resistance). During the research, it was noticed that when the power is directed towards the series compensation device, a greater degree of antiphase of currents is observed at the very first moment rather than when the power is directed from the series compensation device (the greatest degree of antiphase is observed when the onset of a short circuit occurs when the phase voltage vector is in the range of angles $0-30^{\circ}, 180-210^{\circ}$ ). At the same time, when a short circuit occurs in the immediate vicinity of the SCB at the time when the phase voltage is "on the wave crest" $\left(90^{\circ}\right.$ and $\left.270^{\circ}\right)$, small harmonic distortions of currents are observed, both from the side of the uncompensated section and from the side of the series compensation device.

\subsection{Study of the active power flows influence caused by the voltage angle difference at the ends of the power transmission line on the emergency mode parameters of the power transmission line equipped with a series compensation device}

To study the influence of active power flows, symmetrical three-phase short circuits were alternately simulated at points $\mathrm{K} 0-\mathrm{K} 21$ with the following parameters: the voltage of the three-phase sinusoidal voltage sources was the same and amounted to $500 \mathrm{kV}$; the series compensation of inductive resistance: $100 \%$; to load the line with its rated current, the difference in the angles of the same phases in voltage was $6.1^{\circ}$, to load the line with a double rated current, the angle was equal to $12.2^{\circ}$; the transition resistance at the point of the short circuit was $0.01 \mathrm{Ohm}$, as in previous experiments (purely active resistance). During the research, it was found that with an angle difference of $12.2^{\circ}$ (which corresponds to a double line current in terms of thermal resistance) and the direction of active power from the SCB to the short-circuit point at the very beginning of the transient process and throughout the steady-state, the currents are almost antiphase. On the contrary, with an angle difference of $12.2^{\circ}$ and the direction of active power from the point of the short circuit to the SCB at the very beginning of the transient process, the currents are in-phase. Besides, with an angle difference of $12.2^{\circ}$, regardless of the direction of active power, the shortcircuit current at point $\mathrm{K} 10$ (K11) in the steady-state mode is less than the load current.

\section{Conclusion}

With that being said, the following conclusions can be drawn.

1) With a compensation degree of $0 \%$, at the beginning of a short circuit, there is an aperiodic component of the currents from both ends of the line. 
2) With a compensation degree of $5 \%$, a subsynchronous damped sinusoid appears on the capacitor side. The frequency of the subsynchronous sinusoid increases with an increase in the degree of series compensation.

3 ) With a compensation degree of $20 \%$ or more, the frequency of the subsynchronous sinusoid becomes more than half of the power frequency, which is why the phenomenon of amplitude modulation begins to be observed.

4) When the capacitance of the SCB is such that during a short circuit, the degree of compensation of the inductive resistance of the line section, located on the capacitor side relative to the short circuit is close to $100 \%$, the currents are at an angle of $90^{\circ}$, and the transient process on the capacitor side is accompanied by a symmetric exponential increase in amplitude.

5) When the degree of compensation of the longitudinal inductive resistance of the damaged section of the power transmission line is more than $50 \%$, the angles during a short circuit tend to $180^{\circ}$ (i.e., a current inversion occurs).

6) In the case of overcompensation, the transient process behavior is mirrored with respect to one hundred percent compensation of the damaged area: as overcompensation, the subsynchronous frequency begins to decrease.

7) When the line is idling, at the very initial moment of the short circuit, currents flow to the short circuit point.

8) When a short circuit occurs in the immediate vicinity of the SCB at the time when the phase voltage is "on the wave crest" $\left(90^{\circ}\right.$ and $\left.270^{\circ}\right)$, small harmonic distortions of currents are observed, both from the side of the uncompensated section and from the side of the series compensation device.

9) In the presence of a load and the direction of power towards the series compensation device, a greater degree of antiphase of currents is observed at the very first moment rather than when the power is directed from the series compensation device (the greatest degree of antiphase is observed when the onset of a short circuit occurs when the phase voltage vector is in the range of angles $0-30^{\circ}, 180-210^{\circ}$ ).

10) With a difference in the electromotive force angles of the sources equal to $12.2^{\circ}$ (which corresponds to a double line current in terms of thermal resistance) and the direction of active power from the SCB to the short-circuit point at the very beginning of the transient process and throughout the steady-state, the currents are almost antiphase.

11) With an angle difference of $12.2^{\circ}$ and the direction of active power from the point of the short circuit to the SCB at the very beginning of the transient process, the currents are in-phase.

12) With an angle difference of $12.2^{\circ}$, regardless of the direction of active power, the short-circuit current at point $\mathrm{K} 3$ in the steady-state mode is less than the load current.

\section{References}

1. Chernobrovov N. V. Releynaya zashchita [Relay protection]. - Moscow, Energiya Publ., 1974. - 680 p.

2. Fedoseyev A. M. Releynaya zashchita elektricheskikh sistem [Relay protection of electrical systems]. Moscow, Energiya Publ., 1976. -560 p.

3. Moskvin I. A. Ustoychivost' elektroenergeticheskoy sistemy s reguliruyemoy prodol'noy kompensatsiyey. Avtoreferat Kand. Nauk [Stability of the electric power system with adjustable longitudinal compensation. Cand. Diss. Abstract]. Ivanovo, 2014. $20 \mathrm{p}$.

4. Series Compensation. Available at: https://circuitglobe.com/series-compensation.html (accessed 31.07.2020).

5. Martirosyan A.A., Zotova M.V., Kormilitsyn D.N. Selection of installation sites and law of control for controlled series compensation devices in order to improve electric power system stability. Bulletin of the Ivanovo State Power Engineering University, 2017, no 4, pp. 30-36. In Rus.

6. Power transmission capacity upgrade of overhead lines. Available at: https://www.researchgate.net/publication/229000374 _Power_transmission_capacity_upgrade_of_overhea d_lines (accessed 1.08.2020).

7. Kolobrodov Ye.N., Nudel'man G.S. Povysheniye effektivnosti sistem zashchit vozdushnykh liniy sverkhvysokogo napryazheniya $\mathrm{s}$ upravlyayemoy prodol'noy kompensatsiyey [Increasing the efficiency of EHV overhead line protection systems with controlled longitudinal compensation]. IV mezhdunarodnaya nauchno-tekhnicheskaya konferentsiya "Sovremennyye napravleniya razvitiya sistem releynoy zashchity i avtomatiki energosistem» [IV international scientific and technical conference "Modern directions of development of relay protection systems and automation of power systems"]. Yekaterinburg, 2013. pp. 1-8.

8. A review on Series Compensation of Transmission Lines and Its Impact on Performance of Transmission Lines / H. M. Joshi, N. H. Kothari // International journal of engineering development and research, 2014, pp. 72-76.

9. Ivanova VR, Ivanov IY, Novokreshchenov VV. Structural and parametric synthesis of antiaverage control algorithms for realizing adaptive frequency operating automatics electrotechnical systems. Power engineering: research, equipment, technology, 2019, vol. 21, no. 4, pp. 66-76. In Russ.

10. Advances in Series-Compensated Line Protection. Available at: https://cdn.selinc.com/assets/Literature/Publications/ Technical\%20Papers/6340_SeriesCompLineProt_JM 20081022_Web.pdf?v=20150812-154352 (accessed 1.08.2020).

11. Ivanova V.R., Novokreshenov V.V. Issledovaniye funktsional'nykh vozmozhnostey sistem releynoy zashchity i avtomatiki dlya primeneniya ikh $\mathrm{v}$ intellektual'nykh energosistemakh s aktivno- 
adaptivnoy set'yu [The study of the functional capabilitiesof the systems of relay protection and automation for their application in smart grid with active-adaptive network]. IV Natsional'naya nauchno-prakticheskaya konferentsiya "Priborostroyeniye $i$ avtomatizirovannyy elektroprivod v toplivno-energeticheskom komplekse $i$ zhilishchno-kommunal'nom khozyaystve» [IV National Scientific and Practical Conference "Instrument making and automated electric drive in the fuel and energy complex and housing and communal services"]. Kazan, Kazan State Power Engineering University Publ., 2018. vol. 1, pp. 138140.

12. Study on Traveling-wave Differential Protection for Series Compensated Line / F. Chen, G. Qian, F. Wang. Journal of International Council on Electrical Engineering, 2011, Vol. 1, No. 3, pp. 359-366.

13. Ivanova V.R., Ivanov I.YU. Razrabotka kriteriyev otsenki prinimayemykh resheniy $\mathrm{V}$ oblasti proyektirovaniya, sozdaniya i ekspluatatsii aktivnoadaptivnykh elektroenergeticheskikh sistem [Development of criteria for evaluation of the made decisions in the field of design, creation and operation it is active -adaptive electrical power systems]. Mezhdunarodnaya nauchnaya konferentsiya «Vysokiye tekhnologii i innovatsii $v$ nauke» [International scientific conference "High technologies and innovations in science"]. SaintPetersburg, Humanitarian National Research Institute «Natsrazvitiye», 2018. pp. 112-116. 